\title{
Austronesian Expansions and the Role of Mainland New Guinea: A New Perspective
}

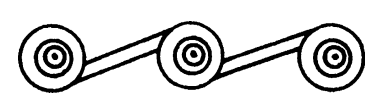

Glenn R. Summerhayes

\begin{abstract}
Recent archaeological discoveries of pottery on mainland New Guinea dating to 3000 years ago have drawn attention to the role of Austronesian expansions that were originally thought to have leapfrogged mainland New Guinea. A review of the evidence from recent excavations provides an assessment of the Neolithic period of New Guinea and its role in facilitating the movement of peoples from Asia into the Pacific. The absence of evidence for occupation along the north and northeast coast of mainland New Guinea is argued to be the result of geomorphological processes rather than an absence of human occupation. KEYwORDS: pottery, trade, mainland New Guinea, Austronesians.
\end{abstract}

\section{INTRODUCTION}

There is CONSENSUS AmONG most ARChAeOlogists that the appearance of Lapita pottery in the western Pacific marks the arrival of Austronesian peoples who colonized the Bismarck Archipelago and then Remote Oceania for the first time some 3200 years ago (Summerhayes 2000, 2007a, 2007b). Although research based on a re-analysis of existing radiocarbon estimates using Bayesian statistics has argued for occupation from 3500 years ago (Denham et al. 2012), the beginning of Lapita occupation by between 3300-3200 years ago is well substantiated by a re-analysis of existing and new dates (Summerhayes 2010).

Where they came from prior to this is highly debated. One school of thought suggests their origins lie in Taiwan, where, with the advent of agriculture, people left the homeland, spread into the Philippines, then eastern Indonesia and the north coast of New Guinea (Bellwood and Dizon 2008; Hung 2008). Another school of thought suggests that these Austronesian speakers originated from a Southeast Asian melting pot, with a combination of peoples, genes, and goods arising from this area (Anderson 2005; Oppenheimer 2004). There is overlap between both models since the Taiwan origin model implies genetic intermixing within Southeast Asia, plus the acquisition of commensal animals along the way. That is, whoever left Taiwan were not the same as those that reached Remote Oceania. However, the archaeological evidence for both models is still patchy and much depends on other lines of evidence such as linguistic interpretations or DNA (Blust 2009; Oppenheimer 2004). 


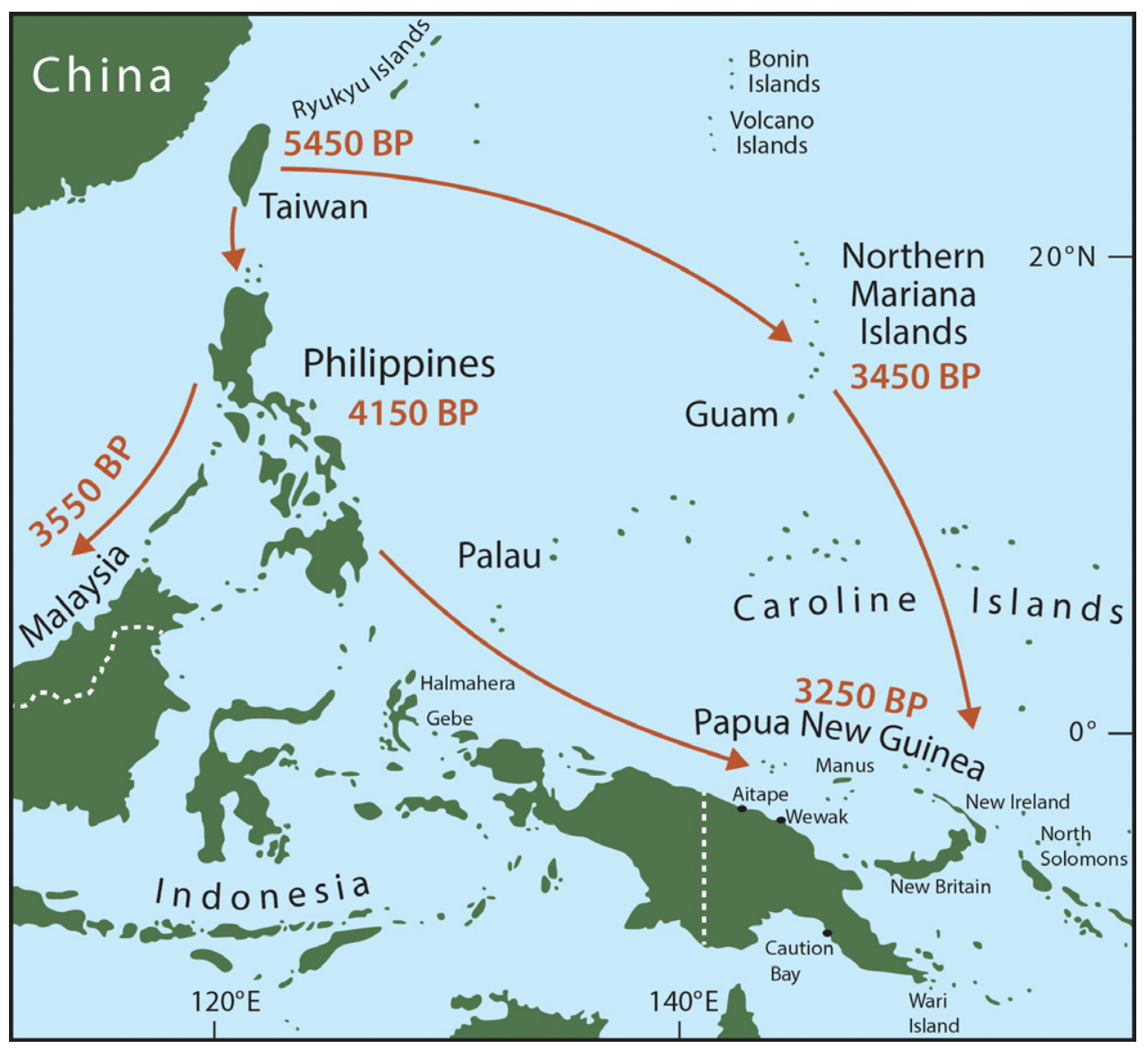

Fig. 1. Movement of Austronesians showing routes and timing through Southeast Asia and into the western Pacific.

The movement of Austronesian speakers out of Taiwan south through the Philippines and eastwards into the Pacific began some four millennia ago (Fig. 1). The appearance of Lapita settlements in the Bismarck Archipelago northeast of mainland New Guinea some 3300 years ago is the archaeological signature of these Austronesian speaking peoples. Yet a major gap in our knowledge occurs in the absence of comparable settlements between Southeast Asia and the western Pacific, with the archaeological signature of that movement missing along the north coast of New Guinea. The lack of evidence for this expansion along the north coast of mainland New Guinea has been argued away, however. Most archaeologists argue that these Austronesians skirted the mainland, bypassing occupied areas that had been inhabited for 50,000 years (Bellwood 2013; Summerhayes et al. 2010).

Archaeologically, the first evidence of Austronesian material culture west of mainland New Guinea is at $3300 \mathrm{cal}$. B.P. Red slipped pottery, with adzes, beads, fish bones, pig bone, and evidence of dogs, has been found in Uattamdi on Kayoa Island, a small island west of Halmahera (Bellwood 1998a, 1998b). However, pottery at other islands (i.e., Morotai, Halmahera, Gebe) dates later, to around ca. 2500-2000 cal. B.P. 
To the east, Lapita pottery is found in the Bismarck Archipelago no earlier than 3300 cal. B.P.(Summerhayes 2010). Gaps remain in between these islands!

Noting the absence of anything "Lapita" along the north coast of New Guinea, most archaeologists have argued that Austronesian speaking peoples from Asia bypassed this land mass and only appeared with the Lapita cultural complex in the islands of the Bismarck Archipelago for the first time. Indeed, over 120 archaeological sites containing Lapita deposits have been identified from the islands making up the Bismarck Archipelago (i.e., New Britain, New Ireland, Manus, north Solomons) (Summerhayes 2007b). However, with the new discoveries of pottery from highland New Guinea sites dating to 3000 years ago (Gaffney et al. 2015), it is time to reflect on the absence of pottery from the north coast of New Guinea, offer a new perspective on occupation along this coastline, and discuss the implications for modelling the movement of peoples from Asia out into the Pacific.

\section{LAPITA ON THE NORTH COAST OF NEW GUINEA}

The identification of two possible occurrences of pottery older than 2000 years provides limited evidence linking Lapita to New Guinea's north coast. Both were found from surface contexts and identified based on the presence of dentate-stamped decoration. The first is a dentate stamped sherd, called the "Aitape Sherd," recovered by Maurice Leask in 1945 in unknown circumstances. Leask enlisted in the Australian Infantry Forces and was attached to the Army Education Services. After Leask's death near Ballarat in 1963, the sherd, along with Leask's major collection from Cape Wom near Wewak, was recovered and sent to Graeme Pretty, a curator at the South Australian Museum. Pretty found the sherd in a bag labelled "Aitape Area." It is a rim sherd with dentate decoration and a channelled lip. The decoration is "Middle Lapita" in style, which dates to the early third millennium B.P.(see image in Swadling et al. 1988:19; fig. 44).

The second dentate sherd was found by Terrell and Welsch (1997:559) on Ali Island (off the coast from Aitape) in an area known as Tubungbale (site code RNJ), a raised marine terrace (Terrell and Welsch 1997:558). On the basis of chemical analysis, it has been argued that the origin of the so-called dentate stamped sherd found on Ali Island is ambiguous, although the evidence presented suggests it was probably made elsewhere (Golitko 2011:264). No petrographic analysis has been undertaken on either sherd. Both sherds have been interpreted by Spriggs (2010:67) as "traded items from the Bismarcks as they are markers of any earlier Lapita spread from the west. It does not seem that they represent the start of a continuous sequence of pottery use to the present in that area."

Pottery does makes an appearance along the north coast, but some 1000 years later. Local pottery production has at least a 2000 year old history on Tumleo Island, a couple of kilometres west of Ali Island (Terrell and Schechter 2011), although the movement of pottery between communities along the north coast occurs much later, only after 1000 years ago (Golitko and Terrell 2012:3578).

THE LAPITA GAP

How has this absence of pottery along northern New Guinea been explained? One model involves purposeful avoidance. Ian Lilley (2008:79) argued that Lapita people 
avoided mainland New Guinea. This is based on the finding of a single, what he called "minute," Lapita dentate-stamped sherd on Ali Island, plus the single piece allocated to Aitape described above. Lilley constructed a model of leapfrogging movements based on fractal geometry. Leaps from Vanuatu to Tonga leapfrogging Fiji are cited, based on pottery distributions and a supposed lack of earlier sites in Fiji, although a highly interactive exchange and interaction system between Lapita peoples including early sites on Fiji could explain this pattern as well. It has also been thought that Austronesian speaking populations bypassed the north coast because it had already been occupied for 50,000 years (Summerhayes et al. 2010).

Another factor in the absence of an Austronesian presence along the north coast is one of simple geography and landforms. The north coastline of Papua New Guinea is a high energy environment lacking fringing coral reefs (Fig. 1). With the exception of Sissano Lagoon near Aitape, the coastline is pounded by the ocean. There is an absence of protected low energy environments and reef platforms such as those found in the Bismarck Archipelago and where Early Lapita stilt houses are found. This area has also been impacted by tsunamis in the remote and recent past (Davies 2017). Similar arguments have been made by Bellwood (2013:194) and Sand and Bedford (2010:19). As Sand and Bedford (2010:19) note, "Only after reaching the Sepik River does one encounter protective islands close to the continental mass before reaching the Bismarck Archipelago." Even here the coastline has been uplifted and altered after numerous volcanic events, including the massive uplift clearly evident along the Madang and Rai Coast, and violent tsunamis (Johnson 2013). If there were Lapita settlements there previously, the archaeology may not be present today.

Despite these limitations, some archaeologists see Austronesian settlement as a possibility. Clark and Bedford (2008:68-70) argue that the boundaries of Lapita will change in the future with more work and modelling based on demographic, environmental, and voyaging variables. Spriggs (1996:334) also noted twenty years ago that evidence of "proto Lapita" should be found along the north coast of New Guinea if Lapita was intrusive from Southeast Asia.

Another model concerns the introduction of Lapita dentate pottery from islands directly north. Carson and colleagues (2013) argued for people moving in from Micronesia as a factor in the appearance of dentate stamped pottery in the Bismarck Archipelago. Yet they also argued that pottery, including plain utilitarian wares, was introduced from the west, entering through Southeast Asia into New Guinea and the Bismarck Archipelago (Carson et al., 2013). The absence of pottery from the north coast of New Guinea has been a problem for this model. On the other hand, Bellwood (2017:287-288) sees no evidence for north coast New Guinea occupation from Southeast Asia: "There is currently no firm linguistic or archaeological evidence to suggest that mainland New Guinea served as a west to east migration route for Neolithic populations speaking Malayo-Polynesian languages and moving from Island Southeast Asia into Oceania." He sees their migratory route as solely occurring through the islands to the north of mainland New Guinea: Marianas, Palau, and the Admiralties (Bellwood 2017:288).

\section{RECENT ADVANCES}

Over the last couple of years major advances have been made in identifying an Austronesian presence on mainland Papua New Guinea. First, evidence of Lapita 


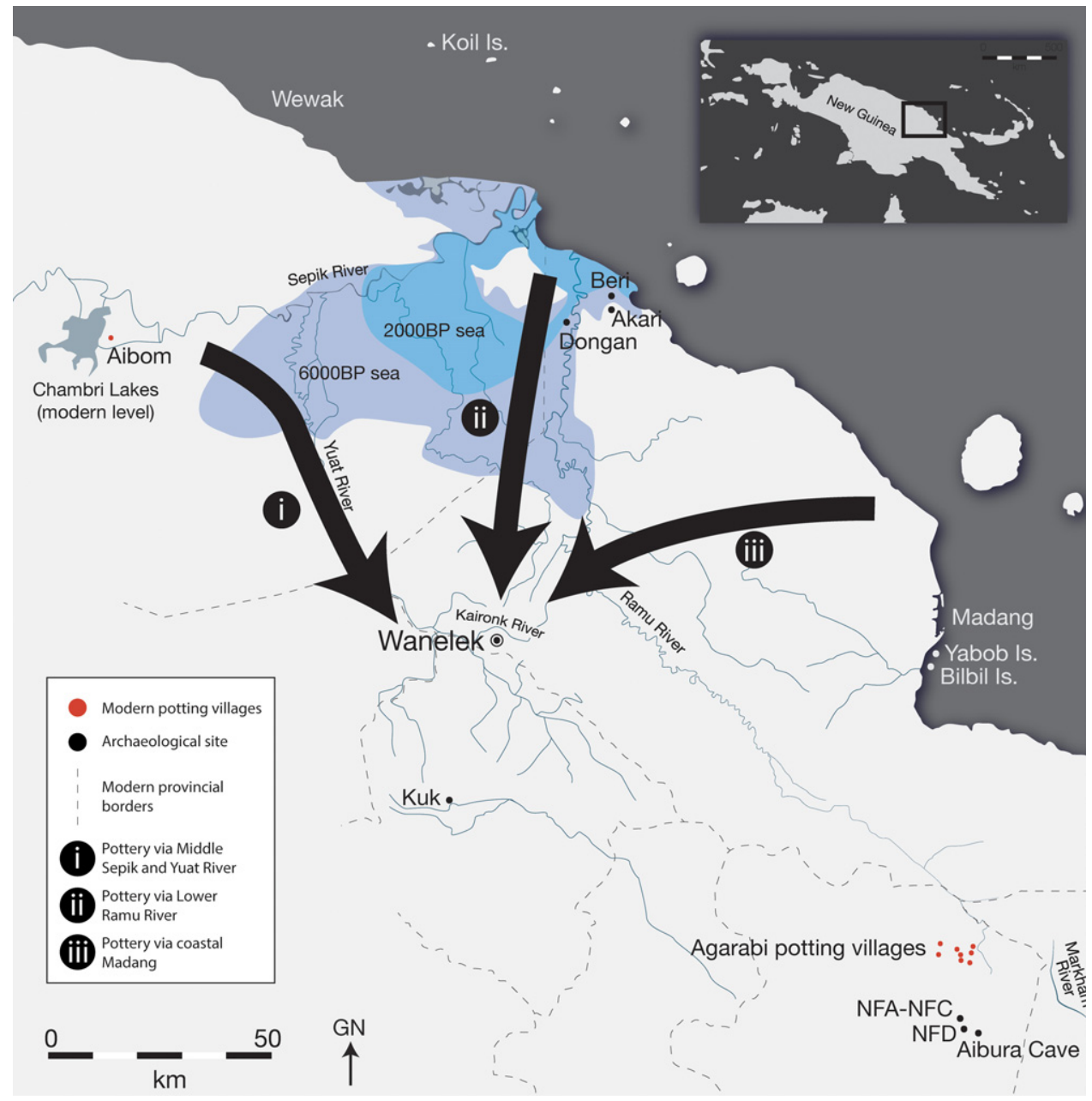

Fig. 2. Northeast New Guinea showing changes in the ancient coastline and possible trade routes for pottery entering the highland interior. (Graphic prepared by Dylan Gaffney.)

settlement has recently been found along the south coast of Papua around Caution Bay, with pottery including dentate stamped motifs and small amounts of obsidian. However, this assemblage is later than the earliest assemblages found in the Bismarck Archipelago, dating from $2900 \mathrm{cal}$. B.P. Furthermore, an examination of the dentatestamped motifs suggests that the site represents what is termed "Middle Lapita" to "Late Lapita" settlement (David et al. 2011; David et al. 2012; David et al. 2013; McNiven et al. 2011; McNiven et al. 2012a; McNiven et al. 2012b). These settlements probably represent colonisation by populations from the Bismarck Archipelago during the Middle Lapita period, the same time colonisers left the Bismarck Archipelago and entered Remote Oceania for the first time (traveling to Vanuatu, New Caledonia, Fiji, Tonga, and Samoa). Late Lapita 2600 year old dentate stamped and shell impressed pottery is also found in the Papuan Gulf at the site of Hopo (Skelly et al. 2014); it bears striking similarities to similarly dated pottery in the Bismarck Archipelago. Plain 
pottery dating to a Late Lapita context had earlier been found on Wari Island off the southeast tip of Papua (Negishi and Ono 2009).

Second, a pottery site from highland New Guinea, Wañelek, has been re-examined with pottery re-dated to between 3000 and 2900 cal. B.P. (Gaffney et al. 2015). Located in the Kaironk Valley of the Bismarck-Schrader Ranges at $1710 \mathrm{~m}$ above sea level, the site was originally excavated by Susan Bulmer in the 1970s (Bulmer 1973) and has recently been the subject of re-examination (Gaffney et al. 2016). Only twenty sherds were recovered from Wanelek, five from recent contexts. What is significant is that based on chemical and petrographic analysis, the pottery from the early levels originated from two different areas: (1) near Chambri Lakes (Middle Sepik); and (2) coastal Madang (Gaffney et al. 2015) (Fig. 2).

There are no archaeological sites of comparable age near Chambri Lakes nor coastal Madang (Gaffney and Summerhayes 2017; Gaffney et al. 2018), although with few archaeologists working in New Guinea and the major geomorphological changes, it is not surprising that none have been found. Pottery that could be of a similar age has, however, been found in the Lower Ramu area at the sites of Beri and Akari (Swadling 1990, 1997; Swadling et al. 1991). They were found in the upper deposits (Swadling and Hope 1992:36).

Lastly, pottery from the Eastern Highlands has been dated to 3200 years ago (Huff 2016). Site NFB, located just over $12 \mathrm{~km}$ south of Kainantu, was excavated in the 1960s by David Cole (Watson and Cole 1977). It yielded 283 ceramic "artefacts" (Huff 2016:84). The earliest association of pottery at the site has been recently reexamined and re-dated to between 3133-3379 cal BP (Huff 2016:84). There are four small plain sherds associated to level III from which the early date is found (Huff 2016:86-87). Pottery above that dates a thousand years later. To date, there have been no petrographic or chemical analyses to identify where the pottery originated, nor any detailed description of the pottery itself.

\section{LINKS BETWEEN THE COAST AND THE INTERIOR OF NEW GUINEA:}

\section{THE SEPIK-RAMU INLAND SEA}

To understand the presence of pottery in the Kaironk Valley and even the Eastern Highlands we need to understand what has been called the "migratory coastline" of the north New Guinea Coast (Swadling and Hope 1992:31) (Fig. 2). The present day Sepik-Ramu lowlands were part of an ancient sea caused by flooding arising out of the last marine transgression (Swadling 1990, 1997; Swadling et al. 1989, 1991; Swadling and Hide 2005). As Swadling and colleagues have noted, over time this inland sea began to recede and disappear with the infilling of sediments from nearby ranges (Swadling et al. 1989; Swadling and Hope 1992:31). The importance of these geomorphological changes is best explained by Swadling: "The Sepik-Ramu sea would have brought the north coast a lot closer to the main intermontane valleys of the Papua New Guinea Highlands, allowing a more direct exchange of ideas and products between the Highlands and the north coast than is the case today" (Swadling and Hope 1992:37; see also Swadling 1997).

Pottery sites mentioned earlier for the Lower Ramu, such as Akari and Beri, would have been located on coastal shorelines or islands in the past. Swadling, Araho, and Ivuyo (1991:92) have argued that the higher ground of the Lower Ramu (such as the Bosman Plateau) would have been islands and an inland brackish water lake would 
have formed during the mid-Holocene. In the highland regions, places that are today seen as inaccessible were in fact much more accessible from the ancient coastlines. Pottery made from the Chambri Lakes region could have been exchanged up what Gorecki and Gillieson (1989:1) call the "Crack in the Spine" following the Yuat River into the highland interior. Pottery from the Lower Ramu could have travelled by sea and river up to what is today Aoime, which is a two day walk to the Simbai and Kaironk valleys. Today, this area is remote from coastal communities, but it was not so remote in the past.

These links between the highlands and lowlands are also witnessed by linguistic data. Foley (1986:278) has argued that the presence of Austronesian loan words in the Enga language demonstrates some kind of Austronesian presence in the Sepik-Ramu basin during the mid to late Holocene. Lynch (1981) earlier pointed out that the Engan language has "quite a large number" of Austronesian loan words, while the Eastern Highlands have a "number" of Austronesian loan words (Foley 1986:277-278). Foley goes further and argues that links between Austronesian settlers and interior populations may have developed in the mid-Holocene with the infilling of the ancient sea:

The situation in the southern high ground would be vastly more complicated. The SepikRamu refugees withdrawing to higher ground from their flooded villages in the proposed salt-water inlet would have come into contact with highlands refugees being pushed out into the fringe areas by the incessantly increasing populations of highland language families. (Foley 1986:279-280)

Despite the models put forward by linguists above, the presence of pottery in highland New Guinea which originated from the Middle Sepik and coastal northeast New Guinea need not have involved population movements, but may simply have been the result of exchange from Austronesian communities. The number of sherds at this site is very low compared to the thousands found at production and consumption sites in the Bismarck Archipelago. But whatever the nature of interaction, the pottery evidence does back up the idea of Austronesian communities living in the Sepik/ Ramu catchments at this time.

Further connections can be seen in highland agricultural practices. It has earlier been argued that the same trade networks that enabled the movement of pottery could also have enabled the movement of cultivars, as witnessed in changes to production at the Highlands site of Kuk (Gaffney et al. 2015). Bayliss-Smith (1996) argued that that Austronesian influences were felt fairly quickly in the Highlands with a second production threshold reached at 2500 years ago that may be related to the arrival of Austronesian speakers on the coast. Gourds were also introduced to New Guinea and adopted by horticulturalists in the Highlands by at least 3000-2000 years ago (Gaffney et al. 2015; Matthews 1983).

\section{CONCLUSIONS}

A lot has happened in New Guinean archaeology over the last five years. Reanalysis of pottery remains from highland New Guinea has placed them in secure 3000 year old contexts. Petrographic and physico-chemical analyses identified their origin as either on the coast or within the ancient inland seas and river systems of the Sepik. The presence of this pottery in the highlands also reconfirms the presence of dentate stamped pottery from coastal locations near Aitape. Connections during the earliest 
Lapita times between the sites in the Bismarcks and the north coast of New Guinea is evident by the presence of a nephrite gouge found on the island of Emirau in Early Lapita contexts and sourced to the north coast of Irian Jaya (Harlow et al. 2012). Obsidian from sources in the Bismarck Archipelago end up in Borneo and the southern Philippines (Reepmeyer et al. 2011). The challenge for us now is to find the expected early settlements along the north coast and pottery producing sites in lowland and coastal New Guinea.

\section{ACKNOWLEDGMENTS}

A great debt of gratitude goes first to Dr. Hsiao-chun Hung for inviting me to present an earlier form of this article to the International Conference of Prehistoric Archaeology in Southeast China through the Pacific and second to Dr. Mike Carson for his encouragement to publish. A big “Thank you!" to Sir Peter Barter for logistical support in Madang. I thank Les O'Neil for help with Figure 1 and Dylan Gaffney for Figure 2 and for his sage comments on this article. Lastly, I thank two anonymous referees for their insightful comments.

\section{REFERENCES CITED}

Anderson, Atholl

2005 Crossing the Luzon Strait: Archaeological chronology of the Batanes Islands, Philippines and the regional sequence of Neolithic dispersal. Journal of Austronesian Studies 1:25-45.

BAyliss-SMith Tim

1996 People-plant interaction in the New Guinea highlands: Agricultural heartland or horticultural backwater?, in The Origins and Spread of Agriculture and Pastoralism in Eurasia: 499-523, ed. David Harris. Washington, D.C.: Smithsonian Institute Press.

Bellwood, Peter

1998a Human dispersals and colonizations in prehistory: The Southeast Asian data and their implications, in The Origins and Past of Modern Humans: Towards Reconciliation: 188-205, ed. Keiichi Omoto and Phillip V. Tobias. Singapore: World Scientific.

1998 From bird's head to bird's eye view; Long term structures and trends in Indo-Pacific prehistory, in Perspectives on the Bird's Head of Irian Jaya, Indonesia: 951-975, ed. Jelle Miedema, Cecilia Ode, and Rien A. C. Dam. Amsterdam: Rodopoi.

2013 First Migrants: Ancient Migration in Global Perspective. Chichester: Wiley Blackwell.

2017 First Islanders: Prehistory and Human Migration in Island Southeast Asia. Hoboken, NJ: Wiley Blackwell.

Bellwood, Peter, and Eusebio Dizon

2008 Out of Taiwan, via the Batanes Islands, and onwards to Western Polynesia, in Past Human Migrations in East Asia: Matching Archaeology, Linguistics and Genetics: 23-39, ed. Alicia SanchesMazas, Roger Blench, Malcom D. Ross, Illia Peiros, and Marie Lin. London: Routledge.

BLust, RoBERT

2009 The Austronesian Languages. Pacific Linguistics 602. Canberra: Research School of Pacific and Asian Studies, Australian National University.

Bulmer, Sue

1973 Notes on 1972 Excavations at Wanlek, an Open Settlement Site in the Kaironk Valley, Papua New Guinea. Auckland: Department of Anthropology, University of Auckland.

Carson, Mike, Hsiao-Chun Hung, Glenn Reginald Summerhayes, and Peter Bellwood

2013 The pottery trail from Southeast Asia to Remote Oceania. Island and Coastal Archaeology $8(1): 17-36$.

Clark, Geoff, and Stuart Bedford

2008 Friction zones in Lapita colonisation, in Islands of Inquiry: Colonisation, Seafaring and the Archaeology of Maritime Landscapes: 59-73, ed. Geoff Clark, Foss Leach, and Susan O'Connor. Terra Australis 29. Canberra: ANU E Press. 
David, Bruno, ian McNiven, Holly Jones-Amin, Sean Connaughton, Charles Parkinson, Cassandra Rowe, Tom Richards, Matthew Leavesley, Bryce Barker, Herman Mandui, Gisella Campanelli, and Nick Flood

2013 Three reconstructed Lapita pots from Caution Bay, south coast of mainland Papua New Guinea, in Pacific Archaeology: Documenting the Past 50,000 Years: 157-170, ed. Glenn Reginald Summerhayes and Hallie Buckley. University of Otago Studies in Archaeology No. 25. Dunedin: University of Otago.

David, Bruno, Ian McNiven, Matthew Leavesley, Bryce Barker, Herman Mandui, Tom Richards, AND Rob SKeLLY

2012 A new ceramic assemblage from Caution Bay, south coast of mainland Papua New Guinea: The Linear Shell Edge-Impressed tradition from Bogi 1. Journal of Pacific Archaeology 3:73-89.

David, Bruno, Ian McNiven, Tom Richards, Sean Connaughton, Matthew Leavesley, Bryce Barker, AND Cassandra Rowe

2011 Lapita sites in the Central Province of mainland Papua New Guinea. World Archaeology 43:576-593.

DAvies, Hugh

2017 Aitape Story: The Great New Guinea Tsunami of 1998. Canberra: Halstead Press.

Denham, Tim, Christopher Bronk Ramsey, and Jim Specht

2012 Dating the appearance of Lapita pottery in the Bismarck Archipelago and its dispersal to Remote Oceania. Archaeology in Oceania 47(1):39-46.

Foley, William

1986 The Papuan Languages of New Guinea. Cambridge: Cambridge University Press.

Gaffney, Dylan, Anne Ford, and Glenn Reginald Summerhayes

2016 Sue Bulmer's legacy in highland New Guinea: A re-examination of the Bulmer Collection and future directions. Archaeology in Oceania 51(S1):23-32.

Gaffney, Dylan, and Glenn Reginald Summerhayes

2017 An Archaeology of Madang, Papua New Guinea. University of Otago Working Papers in Archaeology 5. Dunedin: University of Otago.

Gaffney, Dylan, Glenn Reginald Summerhayes, Anne Ford, Judith Field, Tim Denham, William R. Dickinson, AND JAmes SCOTt

2015 Early Austronesian influences in the New Guinea Highlands at 3,000 years ago. PLOS ONE: 1-15. DOI:10.1371/journal.pone.0134498.

Gaffney, Dylan, Glenn Reginald Summerhayes, Mary Mennis, Teppsy Beni, Affrica Cook, Judith Field, Geraldine Jacobsen, Fran Allen, Hallie Buckley, and Herman Mandui

2018 Archaeological investigations into the origins of Bel trading groups around the Madang coast, northeast New Guinea. Journal of Island and Coastal Archaeology 13:501-530.

Golitko, Mark

2011 Provenience investigations of ceramic and obsidian samples using laser ablation inductively coupled plasma mass spectroscopy and portable X-ray fluorescence, in Exploring Prehistory on the Sepik Coast of Papua New Guinea: 251-287, ed. John Edward Terrell and Esther M. Schechter. Chicago: Fieldiana Anthropology N.S. No. 42.

Golitko, Mark, and John Edward Terrell

2012 Mapping prehistoric social fields on the Sepik coast of Papua New Guinea: Ceramic compositional analysis using laser ablation-inductively coupled plasma-mass spectrometry. Journal of Archaeological Science 39:3568-3580.

Gorecki, Paul, and David S. Gillieson, eds.

1989 A Crack in the Spine: Prehistory and Ecology of the Jimi-Yuat Valley of Papua New Guinea. Townsville: Division of Anthropology and Archaeology, James Cook University.

Harlow, George, Glenn Reginald Summerhayes, Hugh Davies, and Elizabeth Matisoo-Smith

2012 A jade gouge from Emirau Island, Papua-New Guinea (Early Lapita context: 3300 BP): A unique jadeitite. European Journal of Mineralogy 24:391-399.

HuFF, JENNIFER

2016 Revisiting NFB: Ceramic technology in the Eastern Highlands of Papua New Guinea at $3200 \mathrm{cal} \mathrm{BP.} \mathrm{Archaeology} \mathrm{in} \mathrm{Oceania} \mathrm{51(S1):84-90.}$ 
Hung, HSIAO-Chun

2008 Migration and Cultural Interaction in Southern Coastal China, Taiwan and the Northern Philippines, 3000 BC to AD 100: The Early History of the Austronesian-speaking Populations. Unpublished $\mathrm{PhD}$ thesis. Canberra: Australian National University.

Johnson, R. WALLY

2013 Fire Mountains of the Islands. Canberra: ANU E Press.

LiLley, IAN

2008 Flights of fancy: Fractal geometry, the Lapita dispersal and punctuated colonisation in the Pacific, in Islands of Inquiry: Colonisation, Seafaring and the Archaeology of Maritime Landscapes: 75-86, ed. Geoff Clark, Foss Leach, and Susan O'Connor. Terra Australis 29. Canberra: ANU E Press.

LYNCH, JOHN

1981 Austronesian 'loanwords' (?) in Trans-New Guinea phylum vocabulary. Pacific Linguistics A61:165-180.

Matthews, Peter

1983 Identification of Benincasa hispida (wax gourd) from the Kana archaeological site, Western Highlands province, Papua New Guinea. Archaeology in Oceania 38:186-191.

McNiven, Ian, Bruno David, Ken Aplin, Jerome Mialanes, Brit Asmussen, Sean Ulm, Pat Faulkner, Cassandra Rowe, and Tom Richards

$2012 a$ Terrestrial engagements by terminal Lapita maritime specialists on the southern Papuan coast, in Peopled Landscapes: Archaeological and Biogeographic Approaches to Landscapes: 121-156, ed. Simon G. Haberle and Bruno David. Terra Australis 34. Canberra: ANU E Press.

McNiven, Ian, Bruno David, Tom Richards, Ken Aplin, Brit Asmussen, Jerome Mialanes, Matthew Leavesley, Pat Faulkner, and Sean Ulm

2011 New direction in human colonisation of the Pacific: Lapita settlement of south coast New Guinea. Australian Archaeology 72:1-6.

McNiven, I. J., B. David, T. Richards, C. Rowe, M. Leavesley, J. Mialanes, S. Connaughton, B. Barker, K. Aplin, B. Asmussen, P. Faulkner, and S. Ulm

$2012 b$ Lapita on the south coast of Papua New Guinea: Challenging new horizons in Pacific archaeology. Australian Archaeology 75:16-22.

Negishi, Y., AND R. ONO

2009 Kasasinabwana shell midden: The prehistoric ceramic sequence of Wari Island in the Massim, eastern Papua New Guinea. People and Culture in Oceania, 25:23-52.

OPPENHEIMER, S.

2004 The express train from Taiwan to Polynesia: On the congruency of proxy lines of evidence. World Archaeology 36:591-600.

Reepmeyer, Christian, Matthew Spriggs, A. Anggraeni, Peter lape, Leri Neri, Willie P. Ronquillo, Truman Simanjuntak, Glenn Summerhayes, Daud Tanudirjo, and Archie Tiauzoni

2011 Obsidian sources and distribution systems in Island Southeast Asia: New results and implications from geochemical research using LA-ICPMS. Journal of Archaeological Science 38:2995-3005.

Sand, Christophe, and Stuart Bedford

2010 Lapita, archaeological signature of the first Austronesian settlement of the southwest Pacific, in Lapita: Ancêtres Océaniens: 14-27, ed. Christophe Sand and Stuart Bedford. Paris: Musee du Quai Branly.

Skelly, Rob, Bruno David, Fiona Petchey, and Matthew Leavesley

2014 Tracking ancient beach-lines inland: 2600-year-old dentate-stamped ceramics at Hopo, Vailala River region, Papua New Guinea. Antiquity 88(340):470-487.

SPRigGS MATTHEW

1996 What is southeast Asian about Lapita?, in Prehistoric Mongoloid Dispersals: 324-348, ed. Takeru Akazaqa and Emoke J. Szathmary. Tokyo: Oxford University Press.

2010 The Neolithisation of Island southeast Asia, in Lapita: Ancêtres Océaniens: 59-73, ed. Christophe Sand and Stuart Bedford. Paris: Musee du Quai Branly.

Summerhayes, Glenn Reginald

2000 Lapita Interaction. Terra Australis No. 15, Centre of Archaeology, Australian National University. 
2007 a Island Melanesian Pasts - A view from archaeology, in Genes, Language and Culture History in the Southwest Pacific: 10-35, ed. Jonathon Friedlaender. New York: Oxford University Press.

$2007 b$ The rise and transformation of Lapita in the Bismarck Archipelago, in From Southeast Asia to the Pacific. Archaeological Perspectives on the Austronesian Expansion and the Lapita Cultural Complex: 129-172, ed. Scarlett Chui and Christophe Sand. Taipei: Academia Sinica.

2010 Lapita Interaction - An update, in 2009 International Symposium on Austronesian Studies: 11-40, ed. Masegseg Zengror Gadu and Hsiu-man Lin. Taitong: National Museum of Prehistory.

Summerhayes, Glenn Reginald, Matthew Leavesley, Andrew Fairbairn, Herman Mandui, Judith Field, AnNe Ford, and Richard Fullagar

2010 Human adaptation and use of plants in highland New Guinea 49,000-44,000 years ago. Science 330:78-81.

Swadling PAmela

1990 Sepik prehistory, in Sepik Heritage: Tradition and Change in Papua New Guinea: 71-86, ed. Nancy Lukethaus, Christian Kaufmann, William E. Mitchell, Douglas Newton, Lita Osmundsen and Meinhard Schuster. Bathurst: Crawford House.

1997 Changing shorelines and cultural orientations in the Sepik-Ramu, Papua New Guinea: Implications for Pacific prehistory. World Archaeology 29:1-14.

Swadling Pamela, Nick Araho, and Baiva Ivuyo

1989 A Late Quaternary inland sea and early pottery in Papua New Guinea. Archaeology in Oceania 24:106-109.

1991 Settlements associated with the inland Sepik-Ramu Sea. Indo-Pacific Prehistory Association Bulletin 11:92-112.

Swadling, Pamela, Brigitta Hauser-Schaublin, Paul Gorecki, and Frank Tiesler

1988 The Sepik-Ramu: An Introduction. Port Moresby: National Museum with Gordon and Gotch.

Swadling, Pamela, and Robin Hide

2005 Changing landscape and social interaction, looking at agricultural history from a Sepik-Ramu perspective, in Papuan Pasts: Studies in the Cultural, Linguistic and Biological History of the Papuan Speaking Peoples: 289-327, ed. Andrew Pawley, Robert Attenborough, Jack Golson, and Robin Hide. Canberra: Pacific Linguistics, Research School of Pacific and Asian Studies, Australian National University.

Swadling, Pamela, and Geoffrey Hope

1992 Environmental change in New Guinea since human settlement, in The Naïve Lands. Prehistory and Environmental Change in Australia and the Southwest Pacific: 13-42, ed. John Dodson. Melbourne: Longman Cheshire.

Terrell, John Edward, and Esther M. SChechter, eds.

2011 Exploring Prehistory on the Sepik Coast of Papua New Guinea. Fieldiana Anthropology New Series 42. Chicago: Field Museum of Natural History.

Terrell, John Edward, and Robert Welsch

1997 Lapita and the temporal geography of prehistory. Antiquity 21:548-572.

Watson, Virginia, and J. David Cole

1977 Prehistory of the Eastern Highlands of New Guinea. Anthropological Studies in the Eastern Highlands of New Guinea 3. Seattle: University of Washington Press. 